\title{
CONSTITUIÇÃO FEDERAL, CONTROLE JURISDICIONAL E NÍVEIS DE ESCRUTÍNIO
}

\author{
FEDERAL CONSTITUTION, JUDICIAL REVIEW \\ AND LEVELS OF SCRUTINY
}

\author{
CLÈMERSON MERLIN CLÈVE ${ }^{1}$ \\ BRUNO MENESES LORENZETTO ${ }^{2}$
}

\begin{abstract}
RESUMO: O estudo enfatiza a realidade brasileira e ressalta que nossa Constituição Federal possui um sentido substantivo de justiça. Discutem-se os fenômenos do ativismo judicial e da judicialização da política. Assinala as mudanças às quais o Supremo Tribunal Federal foi submetido nos últimos anos e aproxima a doutrina de Carolene Products e os níveis de escrutínio com a jurisdição constitucional nacional, distinguindo entre casos de controle forte e fraco da fiscalização de constitucionalidade.

PALAVRAS-CHAVE: Controle de Constitucionalidade; Democracia; Níveis de Escrutínio.

ABSTRACT: The study emphasizes the Brazilian reality and points out that our Constitution has a substantive meaning of justice. It discusses the judicial activism and judicialization of politics phenomena. It underlines the changes trough which the Supremo Tribunal Federal has undergone in recent years and bring together the Carolene Products doctrine and the levels of scrutiny to the national constitutional jurisdiction, distinguishing between cases of hard and soft judicial review.

KEYWORDS: Judicial Review; Democracy; Levels of Scrutiny.
\end{abstract}

SUMÁRIO: Introdução; 1. O Novo Papel do Supremo Tribunal Federal; 2. Controle de Constitucionalidade e Níveis de Intensidade; Conclusão; Bibliografia.

Artigo recebido em 25.03.2015. Pareceres emitidos em 11.05.2015, 09.06.2015 e 20.10.2015.

Artigo aceito para publicação em 30.10.2015.

${ }^{1}$ Professor Titular de Direito Constitucional da Universidade Federal do Paraná (Curitiba/PR). Professor Titular de Direito Constitucional e Presidente do Centro Universitário Autônomo do Brasil - UniBrasil (Curitiba/PR). Professor do Máster Universitario en Derechos Humanos, Interculturalidad y Desarrollo da Universidad Pablo de Olavide, em Sevilha, Espanha. Pósgraduado em Direito Público pela Université Catholique de Louvain, Bélgica. cleve@uol.com.br

${ }_{2}$ Professor de Direito da Pontifícia Universidade Católica do Paraná (Curitiba/PR). Professor do Mestrado em Direito do Centro Universitário Autônomo do Brasil - UniBrasil (Curitiba/PR). Visiting Scholar na Columbia Law School, Columbia University, New York. Doutor em Direito pela UFPR (Curitiba/PR) na área de Direitos Humanos e Democracia. Mestre em Direito pela UFPR (Curitiba/PR) na área do Direito das Relações Sociais. bruno_lorenzetto@yahoo.com.br 
SUMMARY: Introduction; 1 . The New Role of the Supremo Tribunal Federal; 2. Judicial Review and the Levels of Scrutiny; Conclusion; Bibliography.

\section{INTRODUÇÃO}

A questão circular entre teoria e práxis possui como pano de fundo, na modernidade, o funcionamento de certo conjunto de instituições. No campo jurídico, a jurisdição constitucional e as relações de poder nela imbricadas apresentam especial relevância. A jurisdição constitucional tornou-se um lócus privilegiado da convergência entre a práxis e a teoria, reclamando uma análise crítica acerca do seu lugar e do seu papel na sociedade contemporânea. ${ }^{3}$

A projeção que a jurisdictio passou a ocupar na modernidade é tributária da redefinição do conceito de política. Esta foi distanciada de sua antiga feição aristotélica para assumir posto radicalmente diverso. ${ }^{4}$ Hobbes em sua emblemática obra "O Leviatã", ${ }^{5}$ esquadrinhou o sentido moderno de política da seguinte maneira: i) cabe à política estabelecer as condições adequadas para o funcionamento do Estado e da sociedade (com pretensão de universalização); ii) na transição entre teoria e prática, a aplicação se torna uma questão técnica, com a disposição das condições gerais que organizem o Estado e a sociedade, demandando-se o cálculo correto da produção legislativa, das relações intersubjetivas e do arranjo das instituições; iii) os arquitetos da nova ordem social devem voltar seus esforços no sentido da produção de comportamento calculável. ${ }^{6}$

\footnotetext{
${ }^{3}$ Cabe a ressalva no sentido que, no caso brasileiro, o Supremo Tribunal Federal não é apenas uma Corte Constitucional, portanto, parcela significativa de suas decisões possui escopo restrito às partes envolvidas no processo. Um exemplo de mudanças estruturais significativas na sociedade como um todo foi fornecido por Ronald Dworkin, a respeito do caso Brown v. Board of Education (1954): "Quando a Corte decidiu, em 1954, que nenhum Estado tinha o direito de segregar as escolas públicas por raça, levou o país à mais profunda revolução social já deflagrada por qualquer outra instituição política. (DWORKIN, Ronald. O Império do Direito. São Paulo: Martins Fontes, 2003. p. 4). ${ }^{4}$ A política era compreendida como a continuação da ética e, por isso, o caráter ético da ação (política) não estava separado da lei e dos costumes. A polis era o espaço para a busca da "boa vida". A práxis era distinta da téchne, que se relacionava com a produção de artefatos e o domínio habilidoso de certas atividades. Ante a inconstância ontológica de conceitos abstratos como a Justiça, procura-se, por isso, fazer com que a política (moderna) sirva para assegurar o conhecimento da natureza essencial da justiça, agora identificada ao mundo das leis e contratos. Ver: ARISTOTLE. Politics. London: William Heinemann, 1932; HOBBES, Thomas. Leviatã. São Paulo: Ícone, 2000.

5 "Embora nada do que é feito pelos mortais possa ser imortal, os homens, se usassem a razão como pretendem, poderiam, pelo menos, fazer com que seus Estados fossem assegurados, definitivamente, contra o perigo de perecer por males internos. Pela natureza de sua Instituição, eles estão destinados a viver tanto tempo quanto o gênero humano ou as Leis de Natureza ou, ainda, tanto quanto a própria Justiça, que Ihes dá vida. Assim, quando são dissolvidos, não pela violência externa, mas por desordem intestina, a falta não está nos homens, mas na Matéria; mas, são eles seus modeladores e organizadores". (HOBBES, Thomas. Leviatã. p. 230).

${ }^{6}$ Para Habermas, a separação da política da moralidade substituiu a diretiva que orientava a produção de uma vida "boa" e "justa", com a possibilidade de se fazer uma vida de bem-estar dentro de uma ordem constituída adequadamente. HABERMAS, Jürgen. Theory and Practice. Boston: Beacon Press, 1973. p. 43.
} 
A partir disso, é possível recordar que o início de grandes debates teóricos acaba por remeter, em diversas ocasiões, a questionamentos elementares sobre fatores práticos que permeiam a vida em sociedade, a fundação da comunidade política e a emergência do direito como meio de prevenção e solução de conflitos. Neste contexto cabe perguntar: - Quem define o que é o direito e quem deve obedecê-lo? Quem está autorizado a dizer o direito?

Essas questões, que não demandam respostas definitivas, ensejam diferentes argumentações de acordo com as distintas correntes de pensamento. Todavia, adverte Ronald Dworkin, qualquer teoria do direito deve procurar responder pelo menos a uma parcela desses problemas. Assim, formulações acerca da legislação, da decisão judicial (adjudication) e da observância (compliance) da lei, precisam ser desenvolvidas.

As referidas formulações possuem seus respectivos destinatários: quem produz as leis; quem decide; quem obedece. Enquanto a preocupação daqueles que produzem o conjunto normativo relaciona-se, em princípio, com a questão da legitimidade e com a democracia, a teoria da decisão judicial precisa ser relativamente complexa, contemplando: i) uma "teoria da controvérsia", que estabelece os padrões para a decisão de casos difíceis e, ii) uma "teoria da jurisdição" que defina os motivos e os momentos em que os juízes devem tomar decisões com base na teoria da controvérsia. ${ }^{8}$

Sendo, hoje, insuficiente uma teoria da jurisdição que exponha apenas os argumentos de justificação utilizados pelos juízes, cumpre dialogar com esferas de alto apelo valorativo como a democracia e a justiça.

Diante de tais apelos, procura-se esboçar um diagnóstico do papel da jurisdição constitucional no mundo contemporâneo governado pela ideia de maioria.

\section{O NOVO PAPEL DO SUPREMO TRIBUNAL FEDERAL}

$\mathrm{Na}$ tradição americana a dificuldade da diferenciação entre processos e substâncias decorre da natureza da Constituição, assim como do uso de uma linguagem abstrata sobre os direitos fundamentais. ${ }^{9}$ Ademais, é recorrente a

\footnotetext{
${ }^{7}$ DWORKIN, Ronald. Levando os Direitos a Sério. São Paulo: Martins Fontes, 2010. p. VIII.

${ }^{8}$ DWORKIN, Ronald. Levando os Direitos a Sério. p. IX. Dworkin, por sua vez, apresentou propostas teóricas para a solução de casos difíceis e uma teoria da jurisdição. Tais formulações identificaram os problemas relacionados às tradições do utilitarismo, do realismo e do juspositivismo. Em especial a tradição juspositivista foi criticada por sua incapacidade de compreender a importância de padrões que não são regras, eis que, o positivismo seria um modelo de e para um sistema de regras. Outro aspecto que seria deficitário no repertório juspostivista seria a ausência de uma "teoria da jurisdição". Diante de um caso em que não exista uma regra que possa ser subsumida para solucionar o conflito, o juiz deveria usar seu poder discricionário (judicial discretion) para decidir o caso inédito, o juiz "criaria" uma nova lei. Como forma de enfrentar tal problemática, Dworkin propôs sua própria versão da teoria da controvérsia e da teoria da jurisdição, as quais buscam abranger, ao mesmo tempo, padrões para a solução de casos difíceis e maneiras de apresentar razões nas decisões. DWORKIN, Ronald. Levando os Direitos a Sério. p. 49-50; DWORKIN, Ronald. O Império do Direito.

${ }^{9}$ Mesmo com a abolição da escravidão e com a edição das emendas constitucionais XVIII e XIV,
} 
demanda pela interpretação de princípios implícitos ${ }^{10}$ e a busca por uma "Living Constitution", diante de um texto constitucional lacunoso e antigo. ${ }^{11}$

No Brasil, tais problemas não aparecem com a mesma força. Além de a Constituição ter adotado um rol pormenorizado de direitos fundamentais, ${ }^{12}$ entende-se que estes vinculam a todos, produzindo eficácia vertical e horizontal. ${ }^{13}$ A existência de uma lista detalhada de direitos fundamentais, todavia, não reduz a polêmica em torno da interpretação da Constituição. ${ }^{14}$ Apenas indica que a controvérsia sobre direitos substantivos no Brasil não demanda, na maioria dos casos, apelos a direitos extratextuais. ${ }^{15}$

Cumpre, também, reconhecer que a amplitude dos direitos positivados possibilita a leitura e a defesa de posições substantivas muitas vezes opostas. ${ }^{16}$

a nefasta política do "separados porém iguais" (separted but equal) continuou a ser praticada nos Estados Unidos. A doutrina foi derivada do caso Plessy v. Ferguson (1896), o caso tratou como constitucional uma lei do Estado da Louisiana que determinava diferentes vagões de trem para brancos e negros.

${ }^{10}$ A IX emenda da Constituição dos Estados Unidos faz referência a proteções constitucionais não necessariamente previstas pelo texto da Constituição. Tribe indica a produção de normas substantivas extratextuais: "The idea that the invisible Constitution in fact embodies certain substantive principles central to defining both the structure of government and the rights of persons - and that those norms are parts of the Constitution actually in force rather than of some merely possible Constitution - is likely to be among the most controversial of the propositions put forth in this book". (TRIBE, Laurence. The Invisible Constitution. New York: Oxford University Press, 2008. p. 79).

${ }^{11}$ STRAUSS, David A. The Living Constitution. Oxford: Oxford University Press, 2010.

${ }^{12}$ CLĖVE, Clèmerson Merlin; FREIRE, Alexandre. Direitos Fundamentais e Jurisdição Constitucional. São Paulo: Editora RT, 2014.

${ }^{13}$ SARMENTO, Daniel. Direitos Fundamentais e Relações Privadas. Rio de Janeiro: Lumen Juris, 2003. p. 374-375; SILVA, Virgílio Afonso da. Direitos Fundamentais: conteúdo essencial, restrições e eficácia. 2. ed., São Paulo: Malheiros, 2010.

14 "Sabemos hoje, portanto, que as leis gerais e abstratas não eliminam o problema do Direito, aliás, ao contrário do que igualmente puderam acreditar os iluministas com a sua confiança excessiva na razão, elas inauguram o problema do Direito moderno que é precisamente o da aplicação de normas gerais e abstratas a situações sempre particularizadas, determinadas e concretas." (NETTO, Menelick de Carvalho; SCOTTI, Guilherme. Os Direitos Fundamentais e a (in)certeza do Direito: a produtividade das tensões principiológicas e a superação do sistema de regras. Belo Horizonte: Fórum, 2011. p. 134).

${ }^{15}$ Deve-se ressaltar, ainda, que tal possibilidade não é obstada no país, eis que, para além dos direitos fundamentais positivados, outros decorrentes do regime e dos princípios adotados pela Constituição podem ser incorporados. Art. $5^{\circ} \S 2^{\circ}$ - CF.

16 "Além disso, é fácil perceber o quão tênue é a passagem da aceitação de 'direitos grotescos' para a aceitação de ações sobre cuja inclusão no âmbito de proteção de algum direito fundamental não há consenso. Para ficar em um exemplo simples: festas ao ar livre, em local aberto ao público, estão protegidas pela norma que garante o direito de reunião (art. $5^{\circ}, \mathrm{XVI}$ ? Para a teoria externa e um modelo de suporte fático amplo a resposta é mais que óbvia: prima facie sim, ainda que isso possa ser restringido posteriormente, devido a alguma eventual colisão com outros direitos fundamentais ou interesses coletivos. Para aqueles que sustentam um suporte fático restrito e uma teoria interna a resposta poderá ser não, mas poderá ser sim. O problema é que, uma vez que se negue, a partir de uma concepção restrita e interna, que festas ao ar livre são exercício do direito de reunião, essa decisão, por ser definitiva, tem que valer inclusive nos casos em que tais festas não atrapalhem ninguém e tenham algum interesse público." (SILVA, Virgílio Afonso da. Direitos Fundamentais... p. 154-155) 
Isso decorre das diferenças presentes em uma sociedade extremamente heterogênea como a brasileira, segmentada, fragmentada e caracterizada pela interação de distintos ethos em uma mesma comunidade política. Cada qual formula suas próprias concepções ideológicas, religiosas, de vida digna, o que acaba por repercutir na ampliação da complexidade social. ${ }^{17}$

A definição do Estado brasileiro, disposta na Constituição de 1988, como um Estado Democrático de Direito, resulta de uma decisão política que buscou evidenciar que a democracia não apenas constituiria um valor fundamental, mas, marca constitutiva da identidade constitucional do país. ${ }^{18}$

Ora, o Estado Democrático de Direito deve ser compreendido como um Estado de Justiça. Não de qualquer justiça, subjetiva e arbitrariamente orientada, ou idealisticamente deduzida de parâmetros residentes fora ou sobre a Constituição, mas sim de uma justiça historicamente determinada e juridicamente conformada pela própria Constituição. O ordenamento jurídico do Estado Democrático de Direito há de ser apreendido não apenas como aquele formalmente desenhado pela ação dos órgãos legislativos. Trata-se, antes, de apreendê-lo como bloco de ordenação normativa proveniente da ação daqueles órgãos, mas dotado de um sentido substantivo determinado.

O conteúdo das emanações normativas do Estado brasileiro encontra-se orientado para produzir uma ordem jurídica justa. Nos termos do Preâmbulo da Carta de 1988, os Constituintes reuniram-se para "instituir um Estado Democrático, destinado a assegurar o exercício dos direitos sociais e individuais, a liberdade, a segurança, o bem-estar, o desenvolvimento, a igualdade e a justiça como valores supremos de uma sociedade fraterna, na ordem interna e internacional (...)".

Da atenta leitura da Constituição, é possível deduzir uma série de princípios e objetivos indicadores do conteúdo da dinâmica de conformação legislativa. Referido conteúdo se expressa mediante regras ou princípios plasmados na Constituição (democracia, república, legalidade, segurança, justiça social e igualdade, entre outros) que, agrupados em torno dos direitos fundamentais, produzem o núcleo substantivo da ordem jurídica brasileira.

\footnotetext{
17 "O problema do Direito moderno, agora claramente visível graças a vivência acumulada, é exatamente o enfrentamento consistente do desafio de se aplicar adequadamente normas gerais e abstratas a situações de vida sempre individualizadas e concretas, à denominada situação de aplicação, sempre única e irrepetível, por definição. O Direito moderno, enquanto conjunto de normas gerais e abstratas, torna a sociedade mais e não menos complexa." (NETTO, Menelick de Carvalho; SCOTTI, Guilherme. Os Direitos Fundamentais e a (in)certeza do Direito... p. 127).

${ }^{18}$ Conforme o artigo $1^{\circ}$, caput, da Constituição Federal de 1988. A Constituição alemã, promulgada em maio de 1949, dispõe no art. 20.1: "A República Federal da Alemanha é um Estado Federal, democrático e social". Na Constituição de 1978, art. $1^{\circ}$, o Constituinte espanhol fixou que a "Espanha se constitui em um Estado Social e Democrático de Direito (...)". Quanto à Constituição portuguesa de 1976, no art. $2^{\circ}$, preceitua que "A República Portuguesa é um Estado de Direito Democrático (...)".
} 
Ora, a reserva de justiça condensada na Constituição vincula todos os órgãos constitucionais. ${ }^{19}$ Embora ela autorize várias leituras (comunitária, republicana e liberal igualitária), repelindo outras (libertária, anárquica, perfeccionista ou comunista), condensa um núcleo substantivo compartilhado pelas mais importantes teorias da justiça. Para além disso, cumpre reconhecer que as diferentes concepções de justiça, plurais e substantivas, implicam cosmovisões singulares sobre o que é justo para, completando com conteúdo o conceito formal, fornecer critérios de escrutínio para a qualificação ou justificação de situações (normativas ou fáticas) como justas ou injustas. Ora, numa sociedade aberta e democrática, "na medida em que sabemos onde residem os desacordos, mais possibilidades haverá de superá-los". ${ }^{20}$

De qualquer modo, há na reserva de justiça plasmada na Constituição um núcleo duro que aponta para a igualdade, inclusive fática, simultaneamente direito, princípio e objetivo, enquanto critério para o escrutínio das posições sociais. De modo que, a conexão entre justiça e igualdade deve estar presente não apenas no momento da aplicação do direito, mas também no anterior, identificado com a sua construção normativa e institucional. A igualdade, na hipótese, é "um ideal a ser alcançado, e está implícito em toda e qualquer concepção plausível de justiça política". ${ }^{21}$ Nesse caso, a sociedade é justa porque considera os cidadãos iguais. Ora, "isso exige instituições e normas que promovam a igualdade factual, isto é, políticas sociais de igualação ou equiparação". ${ }^{22}$

Há, contudo, um conjunto de obstáculos na transposição ou tradução das manifestações sociais produzidas no "mundo da vida" e sua compatibilização com os valores substantivos por parte das instituições políticas democráticas. ${ }^{23}$ Um deles diz respeito à desconexão entre representantes e representados. ${ }^{24}$

\footnotetext{
19 "Após a crítica de Rawls ao utilitarismo e de Habermas ao positivismo jurídico e sociológico, que reduziam a normatividade ou a legitimidade do direito à sua própria força, não mais é possível pensar a Constituição e mais ainda as cláusulas constitucionais intangíveis sem levar em conta o seu conteúdo, suas qualidades intrínsecas. Para que certas cláusulas constitucionais possam ser aceitas como limitadoras do poder de cada geração de alterar suas próprias constituições é necessário que o seu conteúdo possa ser justificado e aceito racionalmente. O fato de terem sido estabelecidas por um poder constituinte anterior não é suficiente para garantir a sua legitimidade." (VIEIRA, Oscar Vilhena. A Constituição como Reserva de Justiça. Lua Nova, $n^{\circ}$ 42, 1997. p. 78). CLÉVE, Clèmerson Merlin. Atividade Legislativa do Poder Executivo. São Paulo: Revista dos Tribunais, 2011. p. 138-139.

${ }^{20}$ VELASCO, Marina. O que é Justiça: o justo e o injusto na pesquisa filosófica. Rio de Janeiro: Vieira \& Lent, 2009. p. 55.

${ }^{21}$ VELASCO, Marina. O que é Justiça. p. 91.

${ }^{22}$ VELASCO, Marina. O que é Justiça. p. 91.

23 "Normatively substantive messages can circulate throughout society only in the language of law. Without their translation into the complex legal code that is equally open to lifeworld and system, these messages would fall on deaf ears in media-steered spheres of action. Law thus functions as the 'transformer' that first guarantees that the socially integrating network of communication stretched across society as a whole holds together." (HABERMAS, Jürgen. Between Facts and Norms. Cambridge: The MIT Press, 1998. p. 56).

${ }^{24}$ Para Paul Hirst, a representação não poderia ser melhor analisada se fosse perguntado quão bem um político representa um grupo de vontades, interesses ou indivíduos, para ele tal questão
} 
O legislativo ao mesmo tempo em que viu diminuída sua capacidade de produzir consensos (ainda que contingentes) passou a promover uma substituição na sua atuação por um agir estratégico ou "estatístico". O ideal de democracia representativa continua a ser um pilar fundamental do Estado democrático de Direito, mas se torna insuficiente para lidar com a pluralidade e a complexidade advindas das diferentes identidades sociais dos grupos que compõem o país.

A responsabilidade pela produção de tais consensos passou a ser exercida também, em casos especiais, pelo Judiciário. Neste Poder, os interesses, em sua linguagem ordinária, são recepcionados e transformados em "razões", encontrando uma linguagem técnica que pode acolhê-los, a qual se mantém aberta para recepcionar tais dados do "mundo da vida". Além disso, têm-se a garantia processual do contraditório e de uma resposta institucional, formulada, a priori, de acordo com o conjunto normativo que regula a vida social.

Entende-se, ademais, que o novo papel que o Judiciário assumiu em sua relação com o Legislativo decorre das seguintes reconfigurações: as Cortes passaram a regular a atividade parlamentar ao impor limites substantivos ao processo legislativo através da realização da fiscalização da constitucionalidade; políticas substantivas passaram a ser derivadas da jurisdição; e o Judiciário passou a interferir na própria atividade política, ao impor restrições ao comportamento de grupos de interesse, partidos políticos e de agentes políticos. ${ }^{25}$

John Ferejohn apresenta duas teses para explicar a judicialização da política. ${ }^{26} \mathrm{~A}$ primeira diz respeito à fragmentação do poder dentro dos Poderes, pois, nas situações em que a capacidade de ação política do Poder é constrangida, as pessoas buscam a resolução de seus conflitos em instituições que podem fornecer uma resposta, motivo que leva o Judiciário a substituir o Legislativo em certas ocasiões. A segunda tese é a da hipótese dos direitos, em que as Cortes são observadas como protetoras de valores substantivos importantes contra o potencial abuso político, ou, em outros termos, cumprem a função contramajoritária para proteger minorias - nos termos da teoria derivada do caso Carolene Products. ${ }^{27}$

$\mathrm{Na}$ esfera da jurisdição constitucional tais teses ganham contornos mais salientes. Nas situações em que o Legislativo se recusa a decidir determinada matéria diante de seu potencial custo político, ocorre a transposição da

\footnotetext{
é irresolúvel: "In fact the critique of 'representation' proves one thing, that there is no 'true' form of representation of the interests of the represented. All schemes of representation involve some element of substitution, and all such schemes have distinct political effects." (HIRST, Paul. Representative Democracy and its Limits. Cambridge: Polity Press, 1990. p. 12).

${ }^{25}$ FEREJOHN, John. Judicializing Politics, Politicizing Law. Law and Contemporary Problems, v. $65, n^{\circ} 3,2002$. p. 41.

${ }^{26}$ FEREJOHN, John. Judicializing Politics, Politicizing Law. p. 55.

${ }^{27}$ United States v. Carolene Products Co. (1938).
} 
discussão para o Judiciário que não precisa se preocupar com as consequências eleitorais de suas decisões. ${ }^{28}$

A referida transferência do poder pertencente ao Legislativo para outros âmbitos de decisão também ocorre na sua relação com o Executivo, que dispõe de competência para editar Medidas Provisórias. O Constituinte procurou dotar o Executivo de competência para, sem a necessidade de prévia autorização do Congresso e em situações especialmente relevantes e urgentes, editar comando normativo dotado de força de $\mathrm{le}^{29}$ que, por seu turno, pode operar como um "teste" provisório da legislação definitiva a ser aprovada pelo Congresso. ${ }^{30}$

A judicialização da política em nossa realidade deve ser tratada, portanto, como um fenômeno histórico, derivado da estrutura institucional desenhada pelo Constituinte que, por sua vez, possibilitou a canalização de demandas reprimidas na sociedade durante a ditadura para o texto constitucional. ${ }^{31}$ Como resultado disso, encontra-se uma grande profusão de regras no texto constitucional brasileiro. Por sua vez, os princípios residem, em sua maioria, nos Títulos I e II, na parte da "reserva de justiça", que cuida dos direitos fundamentais. ${ }^{32}$

\footnotetext{
${ }^{28}$ Sob um enfoque tradicional, uma das principais funções do controle de constitucionalidade é o de limitar decisões políticas majoritárias contrárias à Constituição e promover sua retirada do ordenamento jurídico, mesmo nas situações em que a lei é defendia pela maior parte da população. Dentro de tal perspectiva, seria inconsistente com o papel de um judiciário independente a consideração pelas Cortes dos efeitos públicos da decisão no sentido de esta causar comoção nacional ou mobilizações contrárias. Sunstein sugere duas estratégias, a consequencialista e a epistêmica, que qualificam a discussão a respeito dos impactos públicos da decisão da Corte, ver: SUNSTEIN, Cass. If People Would be Outraged by Their Rulings, Should Judges Care? Stanford Law Review, v. 60, 2007.

${ }^{29}$ CLÈVE, Clèmerson Merlin. Medidas Provisórias. 3. ed., São Paulo: RT, 2010. p. 44.

30 "A compreensão do art. 62 da Constituição não pode ser prisioneira da interpretação literal. Apenas uma interpretação sistemática é capaz de revelar o sentido do dispositivo constitucional. Por esta razão, uma vez adotada, a medida provisória (lei ou ato legislativo) deve ser submetida, imediatamente, ao Congresso Nacional, para conversão em lei formal. Está-se referindo, então, à conversão de lei precária em lei permanente derivada do processo público inerente à elaboração da lei formal. Nada mais do que isso: uma espécie de lei (a medida provisória: ato provisório) é convertida em outra espécie de lei (a lei formal, no caso, lei ordinária: ato permanente)." (CLĖVE, Clèmerson Merlin. Medidas Provisórias... p. 76-77).

31 "A primeira grande causa da judicialização foi a redemocratização do país, que teve como ponto culminante a promulgação da Constituição de 1988. Nas últimas décadas, com a recuperação das garantias da magistratura, o Judiciário deixou de ser um departamento técnico-especializado e se transformou em um verdadeiro poder político, capaz de fazer valer a Constituição e as leis, inclusive em confronto com os outros Poderes. (...) A segunda causa foi a constitucionalização abrangente, que trouxe para a Constituição inúmeras matérias que antes eram deixadas para o processo político majoritário e para a legislação ordinária. (...) A terceira e última causa da judicialização, a ser examinada aqui, é o sistema brasileiro de controle de constitucionalidade, um dos mais abrangentes do mundo." (BARROSO, Luís Roberto. Judicialização, Ativismo Judicial e Legitimidade Democrática. Revista de Direito do Estado, n 13, jan./mar. 2009. p. 73-74).

${ }_{32} \mathrm{Um}$ exemplo disso encontra-se na possível dicotomia que pode ser extraída do texto constitucional, tanto no sentido de perspectivas filosóficas heterônomas como outras que procurem garantir amplíssima autonomia para os indivíduos. Tais perspectivas filosóficas colidem em situações que envolvam casos difíceis (ou decisões trágicas).
} 
Entende-se que modificações no atual estado do fenômeno da judicialização da política não irão ocorrer no Brasil, a não ser que uma profunda reforma constitucional venha a redefinir a identidade constitucional vigente no país. ${ }^{33}$

Se até o advento da Constituição Federal de 1988 a via mais comum de manifestação do controle de constitucionalidade brasileiro era a difusa, a partir de então se destacou a fiscalização abstrata. Isso pela previsão de novas ações que desencadeiam a fiscalização em tese, pelo aumento do rol de legitimados ativos e pela previsão de mecanismos que potencializam o controle abstrato.

O significativo número de ações diretas que tramitam no STF reflete não só o incremento do controle abstrato, mas também da própria jurisdição constitucional brasileira. ${ }^{34}$ Com a Constituição de 1988, fez-se valer a tese da força normativa das disposições constitucionais, o que acarretou maior atuação da jurisdição constitucional.

Deve-se ressaltar que o Judiciário brasileiro não encontra modelo correspondente no âmbito internacional, isso porque a Constituição de 1988, como nenhuma outra, conferiu-Ihe um papel singular. O Constituinte, diante de um passado de ausência de enraizamento das Constituições, procurou conferir ao Judiciário um padrão de atuação capaz de auxiliar de maneira poderosa no processo de efetividade da Constituição.

Mas se, por um lado e em um primeiro momento, a tônica do constitucionalismo brasileiro foi a efetividade das normas constitucionais, aprendida essa lição, chega-se ao momento de pontuar as tensões que o crescimento da atividade judicial encerra com os postulados democráticos. Não se trata de defender uma postura deferente da jurisdição constitucional em todos os momentos, mas sim considerar que a sua atuação pode ser problemática em um ambiente marcado pelo compromisso democrático. ${ }^{35}$

Por isso, a jurisdição constitucional no Brasil precisa buscar um difícil equilíbrio no que diz respeito à separação de poderes e à necessidade do Supremo Tribunal Federal fazer cumprir a Constituição. ${ }^{36}$ Esta, conforme já

${ }^{33}$ BARROSO, Luís Roberto. O Novo Direito Constitucional Brasileiro: contribuições para a construção teórica e prática da jurisdição constitucional no Brasil. Belo Horizonte: Fórum, 2012. p. 244.

${ }^{34}$ Não só ocorreu o incremento da fiscalização abstrata, mas também se observa uma "abstrativização" do controle concreto. Nesse sentido, o Supremo já aplicou a técnica da modulação de efeitos (natural do controle abstrato) em sede de controle incidental (RE-AgR $n^{\circ}$ 516.296, Rel. Min. Joaquim Barbosa, j. 10.04.2007); conferiu efeitos gerais à decisão proferida no Mandado de injunção n 670 (MI no 670, Rel. Min. Gilmar Mendes, j. 25.10.2007, Informativo STF 485), instrumento que desencadeia uma fiscalização incidental da constitucionalidade.

${ }^{35}$ CLÉVE, Clèmerson Merlin. Temas de Direito Constitucional. 2. ed., Belo Horizonte: Fórum, 2014. p. 395-396.

${ }^{36}$ Para Conrado Mendes: "Na separação de poderes, a interação é inevitável. A interação deliberativa é um ganho; a interação puramente adversarial, se não chega a ser uma perda, desperdiça seu potencial epistêmico. (...) A revisão judicial não precisa ser vista apenas como um dique ou uma barreira de contenção, mas também como um mecanismo propulsor de melhores deliberações. Não serve somente para (tentar) nos proteger da política quando esta sucumbe ao pânico ou 
anotado, ostenta natureza expansiva, o que implica aumento do âmbito de atuação do "guardião constitucional". 37

Há muitas decisões prolatadas pelo Supremo Tribunal Federal em casos difíceis. ${ }^{38}$ Elas, porém, não compõem a maioria de suas decisões. Ademais, o modus adotado pela Corte para solucionar questões polêmicas nem sempre supõe adoção de orientação ativista.

O ativismo, presente em decisões expansivas que cruzam os limites traçados previamente para a atuação do Judiciário, se manifesta, muitas vezes, em situações de déficit de atuação dos demais Poderes, especialmente para a proteção de grupos minoritários ou vulneráveis. ${ }^{39}$ Contudo, em diversas oportunidades, o STF decidiu de maneira diversa, optando pela deferência diante dos outros Poderes, mesmo em situações que envolviam casos difíceis. ${ }^{40}$

irracionalidade, mas para desafiá-la a superar-se em qualidade." (MENDES, Conrado Hübner. Direitos Fundamentais, Separação de Poderes e Deliberação. São Paulo: Saraiva, 2011. p. 211-212).

${ }^{37}$ A crítica normativa ao papel de "guardião" do STF não modifica sua função estrutural, porém, é relevante por apontar para outras formas de interação institucional e procurar superar a traiçoeira questão da "última palavra": "O tipo deliberativo de interação é o ideal que permeia, portanto, esse exercício. Dá uma justificativa condicionada para o papel do STF, mas, ao mesmo tempo, tira-o do pedestal de 'guardião'. (...) Mas não recusa, ao mesmo tempo, a legitimidade de o STF praticar um acentuado ativismo em certas circunstâncias. Isso está em sintonia com a concepção de separação de poderes delineada no capítulo anterior, segundo a qual não há (e nem pode haver) receitas abstratas e prefixadas que esgotem a definição das funções." (MENDES, Conrado Hübner. Direitos Fundamentais, Separação de Poderes e Deliberação... p. 214).

${ }^{38}$ Dworkin explica que: "(...) mesmo quando nenhuma regra regula o caso, uma das partes pode, ainda assim, ter o direito de ganhar a causa. O juiz continua tendo o dever, mesmo nos casos difíceis, de descobrir quais são os direitos das partes, e não de inventar novos direitos retroativamente. Já devo adiantar, porém que essa teoria não pressupõe a existência de nenhum procedimento mecânico para demonstrar quais são os direitos das partes nos casos difíceis." (DWORKIN, Ronald. Levando os Direitos a Sério. p. 127).

${ }^{39}$ Para Barroso: "A idéia de ativismo judicial está associada a uma participação mais ampla e intensa do Judiciário na concretização dos valores e fins constitucionais, com maior interferência no espaço de atuação dos outros dois Poderes. A postura ativista se manifesta por meio de diferentes condutas, que incluem: (i) a aplicação direta da Constituição a situações não expressamente contempladas em seu texto e independentemente de manifestação do legislador ordinário; (ii) a declaração de inconstitucionalidade de atos normativos emanados do legislador, com base em critérios menos rígidos que os de patente e ostensiva violação da Constituição; (iii) a imposição de condutas ou de abstenções ao Poder Público, notadamente em matéria de políticas públicas." (BARROSO, Luís Roberto. Judicialização, Ativismo Judicial e Legitimidade Democrática... p. 75). Anota Carlos Campos que: "Embora incontestável do ponto de vista descritivo, o ativismo judicial não é uma unanimidade sob a perspectiva normativa. A ascensão política de juízes e cortes sempre foi alvo de muitas críticas. A prática é acusada de afrontar o princípio democrático e o valor do autogoverno popular. Fala-se em mutação do 'Estado legislativo parlamentar em um Estado Jurisdicional governado pelo Tribunal Constitucional' e que 'esse Tribunal torna-se, em sentido peculiar, o soberano da constituição' em clara violação ao princípio da separação de poderes." (CAMPOS, Carlos Alexandre de Azevedo. Dimensões do Ativismo Judicial do Supremo Tribunal Federal. Rio de Janeiro: Forense, 2014. p. 35).

${ }^{40}$ Três casos emblemáticos podem ser citados para ilustrar o argumento. 1) No caso da demarcação de terras indígenas, conhecido como Raposa Serra do Sol (PET 3388, RR, Rel. Carlos Brito, j. 19.03.2009, DJE 25.09.2009), tem-se na Constituição definido em regra a propósito do domínio de tais áreas pelas populações indígenas e por populações tradicionais, como os quilombolas. A regra já vinha sendo manejada pelo Executivo no sentido de sua concretização, com a 
Do passado quase silencioso imposto ao Judiciário, passou-se para um paradigma da necessária interação com os outros Poderes, em certos momentos, no sentido da cooperação, em certas ocasiões, como freio, ou mesmo como protagonista de uma tensão produtiva. ${ }^{41}$

No Brasil, faz-se possível notar a aproximação paulatina entre o modelo americano, em que se privilegia o controle difuso de constitucionalidade, ${ }^{42}$ e o modelo europeu, ${ }^{43}$ no qual há a ênfase no controle concentrado de constitucionalidade e uma Corte Constitucional responsável pela jurisdição constitucional. O Supremo Tribunal Federal, contemporaneamente, apesar de manifestações favoráveis nesse sentido, ainda não assumiu o papel de uma verdadeira instância limitada à "guarda da Constituição", ou de Corte Constitucional. ${ }^{44}$

Há, ainda, a convergência entre as formas de controle difuso-incidental e concentrado-principal. Afinal, ambos se orientam no sentido da proteção de direitos substantivos referenciados nos direitos fundamentais dispostos na Constituição. Por isso, pode-se afirmar que o controle abstrato não está limitado à defesa da ordem constitucional objetiva. ${ }^{45}$

competência do Presidente da República para definir a demarcação da área - seria possível a transferência de tal poder para o Legislativo, caso ela viesse a ser regulamentada em lei. No momento da decisão pelo STF de tal questão, a Corte, em termos gerais, não foi ativista excepcionados os dispositivos estipulados pelo Min. Menezes Direito que tiveram de ser julgados novamente pelo próprio STF. No julgamento dos Embargos de Declaração do caso em 2013 (PET 3388 ED, RR, Rel. Min. Roberto Barroso, j. 23.10.2013, DJE 04.02.2014), o relator, Min. Roberto Barroso, afastou o caráter vinculante das condicionantes e explicou que as diretrizes não poderão ser objeto de questionamento em outros processos. Prestou-se, portanto, deferência ao Executivo, que dispõe de melhores meios técnicos para conhecer a matéria, como, por exemplo, a realização de estudos antropológicos. 2) A Lei da Biossegurança (11.105/2005), seguiu um processo legislativo permeado por grandes discussões promovidas pelo próprio Legislativo, próximas ao desejável para qualquer matéria que venha a ser submetida ao apreço do legislador. A decisão do STF (ADI 3510, Rel. Min. Carlos Britto, j. 29.05.2008, DJE 28.05.2010), também auxiliada pela participação popular via audiências públicas, prestou deferência ao processo legislativo ao reconhecer a constitucionalidade da lei. 3) No caso da união estável de pessoas do mesmo sexo (ADPF 132, Rel. Min. Carlos Britto, j. 05.05.2011, DJE 14.10.2011), pode-se dizer que o STF assumiu uma postura mais ativista ao utilizar a técnica da interpretação conforme a Constituição, contudo, esta foi feita dentro da lógica de proteção de grupos minoritários, uma das razões que justificam a própria jurisdição constitucional.

41 "Um desenho institucional consiste na alocação de faculdades de estatuir e da faculdades de vetar em diferentes agentes. Entre vetos e estatuições, desenha-se um processo decisório, distribuem-se poderes, moldam-se incentivos institucionais, criam-se canais saudáveis de interlocução. Numa sucessão de testes, uma decisão coletiva finalmente é tomada. (...) O controle de constitucionalidade seria uma veto a mais na intrincada rede das faculdades de vetar e estatuir que compõe a engenharia da separação de poderes." (MENDES, Conrado Hübner. Controle de Constitucionalidade e Democracia. Rio de Janeiro: Elsevier, 2008. p. 132).

${ }^{42}$ Marbury v. Madison (1803).

${ }^{43}$ KELSEN, H. Jurisdição Constitucional. São Paulo: Martins Fontes, 2007.

${ }^{44}$ CLĖVE, Clèmerson Merlin. A Fiscalização Abstrata de Constitucionalidade no Direito Brasileiro. 2. ed., São Paulo: RT, 2000. p. 413.

45 "As três dimensões anteriormente analisadas - juridicidade, constitucionalidade, direitos fundamentos - indiciam já que o princípio do estado de direito é informado por duas idéias 
Não há dúvidas, portanto, do fortalecimento gradual do Judiciário e em especial do Supremo Tribunal Federal, após a estabilização democrática do Brasil. Tal constatação não procura desviar a atenção para o aspecto eminentemente agonista, adversarial que caracteriza a democracia. ${ }^{46}$ Pelo contrário, com a estabilização e a constância de certo conjunto de processos elementares a garantir a democracia durante as duas últimas décadas, manifestou-se o aprofundamento das discussões políticas e a inclusão de novos problemas para deliberação na arena pública. Contudo, mesmo diante da aposta constitucional na democracia representativa e no protagonismo do Legislativo, a inércia deste em certas ocasiões acaba por deixar espaços de poder "vazios" que são preenchidos pelo Judiciário, tanto que algumas justificativas do ativismo judicial são tecidas em torno das omissões dos demais Poderes. ${ }^{47}$

Sendo certo que o ativismo do Supremo Tribunal Federal não deve ser confundido com o de todo o Judiciário, as razões apresentadas para embasar uma postura menos deferente por parte da Corte são, em geral, as seguintes: i) a Constituição é uma Ordem Fundamental "guardiã" de princípios substantivos e não apenas uma "Lei Quadro"48; ii) a defesa de direitos fundamentais e dos princípios fundamentais que estão na base de nossa comunidade política é tarefa do Judiciário; ${ }^{49}$ iii) tal tarefa reclama, muitas vezes, o uso de novas

ordenadoras: (1) idéia de ordenação subjectiva, garantindo um status jurídico aos indivíduos essencialmente ancorado nos direitos fundamentais; (2) ideia de ordenação objectiva, assente no princípio da constitucionalidade, que, por sua vez, acolhe como princípio objectivamente estruturante o princípio da divisão de poderes. Essas duas dimensões não se divorciam uma da outra, mas o acento tônico caberá agora à ordenação funcional objectiva do Estado de direito." (CANOTILHO, J. J. Gomes. Direito Constitucional e Teoria da Constituição. 7. ed., Coimbra: Almedina, 2003. p. 250).

${ }^{46}$ Chantal Mouffe lembra que a democracia é algo frágil que ela precisa ser defendida constantemente: MOUFFE, Chantal. El Retorno de lo Político. Barcelona: Paidós, 1999.

${ }^{47}$ Sobre o ativismo Carlos Campos pontua acerca de sua multimensionalidade: "Essas decisões apresentam diferentes dimensões, e não apenas forma única de manifestação, o que significa dizer que o ativismo judicial consiste em práticas decisórias, em geral, multifacetadas e, portanto, insuscetíveis de redução a critérios singulares de identificação. Há múltiplos indicadores do ativismo judicial como a interpretação expansiva dos textos constitucionais, a falta de deferência institucional aos outros poderes de governo, a criação judicial de normas gerais e abstratas, etc." (CAMPOS, Carlos Alexandre de Azevedo. Dimensões do Ativismo Judicial do Supremo Tribunal Federal... p. 163).

${ }^{48}$ Lei cujas disposições genéricas orientam a aplicação das normas de um determinado ordenamento jurídico. Ver: CANOTILHO, J. J. Gomes. Direito Constitucional e Teoria da Constituição... p. 785-786.

${ }^{49}$ Nesse sentido, Dworkin enfatiza a importância de argumentos de princípio ao invés de argumentos políticos no exercício da jurisdição constitucional: "Se queremos a revisão judicial - se não queremos anula Marbury contra Madison - devemos então aceitar que o Supremo Tribunal Federal deve tomar decisões políticas importantes. A questão é que motivos, nas suas mãos, são bons motivos. Minha visão é que o Tribunal deve tomar decisões de princípio, não de política decisões sobre que direitos as pessoas têm sob nosso sistema constitucional, não decisões sobre como se promove melhor o bem-estar geral -, e que deve tomar essas decisões elaborando e aplicando a teoria substantiva da representação, extraída do princípio básico de que o governo deve tratar as pessoas como iguais." (DWORKIN, Ronald. Uma Questão de Princípio. São Paulo: Martins Fontes, 2005. p. 101). 
técnicas de decisão para fazer face à complexidade social nacional e promover sentidos de justiça constitucional; iv) o ativismo da Corte é subsidiário, aparecendo apenas nas circunstâncias de inércia dos demais Poderes.

O fortalecimento do Supremo Tribunal Federal pode ser explicado, também, em decorrência de outros fatores. O efeito vinculante de suas decisões, ${ }^{50}$ a repercussão geral no recurso extraordinário ${ }^{51}$ e a possibilidade de edição de súmulas vinculantes ${ }^{52}$ são mecanismos que foram acompanhados por novas técnicas de decisão como a interpretação conforme, a declaração de inconstitucionalidade sem redução de texto, ${ }^{53}$ o apelo ao legislador, ${ }^{54}$ a maior atenção ao instituto da reclamação, ${ }^{55}$ e propostas polêmicas como a vinculação à ratio decidendi e a transcendência dos motivos determinantes das decisões. ${ }^{56}$

${ }^{50}$ RCL 2189 MS, Rel. Min. Gilmar Mendes, j. 03.02.2003, DJU 07.02.2003. BINENBOJM, Gustavo. A Nova Jurisdição Constitucional. 2. ed., Rio de Janeiro: Renovar, 2004. p. 195.

${ }^{51}$ Art. 102, - CF: "§ $3^{\circ}$ No recurso extraordinário o recorrente deverá demonstrar a repercussão geral das questões constitucionais discutidas no caso, nos termos da lei, a fim de que o Tribunal examine a admissão do recurso, somente podendo recusá-lo pela manifestação de dois terços de seus membros". A repercussão geral foi regulamentada pela Lei 11.418 de 19.12.2006. O STF, por sua vez, editou a Emenda Regimental $n^{\circ} 21$, de 30.04.2007.

52 "É evidente, porém, que a súmula vinculante, como o próprio nome indica, terá o condão de vincular diretamente os órgãos judiciais e os órgãos da Administração Pública, abrindo a possibilidade de que qualquer interessado faça valer a orientação do Supremo, não mediante simples interposição de recurso, mas por meio de apresentação de uma reclamação por descumprimento de decisão judicial (CF, art. 103-A)" (MENDES, Gilmar Ferreira; BRANCO, Paulo Gustavo Gonet. Curso de Direito Constitucional. 7. ed., São Paulo: Saraiva, 2012. p. 1040).

53 "Como técnica de interpretação, o princípio impõe a juízes e tribunais que interpretem a legislação ordinária de modo a realizar, da maneira mais adequada, os valores e fins constitucionais. Vale dizer: entre interpretações possíveis, deve-se escolher a que tem mais afinidade com a Constituição. (...) Como mecanismo de controle de constitucionalidade, a interpretação conforme a Constituição permite que o intérprete, sobretudo o tribunal constitucional, preserve a validade de uma lei que, na sua leitura mais óbvia, seria inconstitucional. Nessa hipótese, o tribunal, simultaneamente, infirma uma das interpretações possíveis, declarando-a inconstitucional, e afirma outra, que compatibiliza a norma com a Constituição. Trata-se de uma atuação 'corretiva', que importa na declaração de inconstitucionalidade sem redução de texto." (BARROSO, Luís Roberto. Curso de Direito Constitucional Contemporâneo: os conceitos fundamentais e a construção do novo modelo. São Paulo: Saraiva, 2009. p. 301).

54 "O constituinte de 1988 criou dois instrumentos para lidar com as omissões inconstitucionais: o mandado de injunção e a ação direta de inconstitucionalidade por omissão. Atendeu, assim, a um reclamo generalizado da sociedade e da doutrina em busca de maior efetividade para as normas constitucionais, enfrentando uma das principais disfunções históricas do constitucionalismo brasileiro." (BARROSO, Luís Roberto. O Controle de Constitucionalidade no Direito Brasileiro: exposição sistemática da doutrina e análise crítica da jurisprudência. São Paulo: Saraiva, 2011. p. 153-154).

55 "A jurisprudência do Supremo Tribunal, no tocante à utilização do instituto da reclamação em sede de controle concentrado de normas, deu sinais de grande evolução no julgamento da questão de ordem em agravo regimental no Rcl. 1.880, em 23.05.2002, quando a Corte restou assente o cabimento da reclamação para todos aqueles que comprovarem prejuízo resultante de decisões contrárias às teses do STF, em reconhecimento à eficácia vinculante erga omnes das decisões de mérito proferidas em sede de controle concentrado. (MENDES, Gilmar Ferreira; BRANCO, Paulo Gustavo Gonet. Curso de Direito Constitucional... p. 1456).

56 "Em sucessivas decisões, Supremo Tribunal Federal estendeu os limites objetivos e subjetivos das decisões proferidas em sede de controle abstrato de constitucionalidade, com base em uma 
Tudo isso levou a uma revisão do próprio papel que o Supremo Tribunal Federal exercia na jurisdição constitucional, com a releitura e potencialização dos institutos processuais dispostos originariamente pelo Constituinte.

Qual seria, afinal, o papel do Supremo Tribunal Federal dentro do desenho institucional estabelecido pelo Constituinte em um projeto original, em uma forma inicial, e inevitavelmente modificado e adaptado ao longo dos anos? A Corte seria um espaço deliberativo revisional, de reexame de leis que se supõem já terem sido objeto de discussões no Parlamento? O seu papel seria o de apresentar remédios fortes ou fracos diante de eventuais violações à Lei Fundamental? ${ }^{57}$ Pois, não apenas o STF precisa se questionar constantemente sobre o seu papel - quais motivações justificam a realização do controle de constitucionalidade - mas, também, sobre a intensidade do controle a realizar.

Entende-se, diante de tais problemas, que ao Supremo Tribunal Federal não caberia nem a adoção do ativismo, nem uma postura que abrace apenas a deferência como orientação. A insuficiência de tais modelos, para além do pêndulo político que pode existir dentro da configuração ideológica da Corte, foi constatada nos diferentes arranjos aos quais a Suprema Corte americana foi submetida.

O ativismo pode ser, em determinada conjuntura histórica, uma peça fundamental para promover direitos civis, mas, o mesmo discurso pode ser também manejado para a desconstrução de conquistas alcançadas duramente por uma geração. A defesa do enfraquecimento do papel da Corte aparenta ser uma medida radical de um contexto que nos é estranho. A postura, hoje, decorre da longa duração de uma Corte conservadora nos Estados Unidos que vai moldando, através de suas sucessivas decisões, aspectos determinantes da comunidade política americana.

Tal realidade, que encontra nos últimos tempos os progressistas defendendo outros lugares de produção jurídica para além da Corte, acaba por operar o retorno do problema sem fim que o controle de constitucionalidade apresenta.

construção que vem denominando transcendência dos motivos determinantes. Por essa linha de entendimento, é reconhecida eficácia vinculante não apenas à parte dispositiva do julgado, mas também aos próprios fundamentos que embasaram decisão. Em outras palavras: juízes e tribunais devem acatamento não apenas à conclusão do acórdão, mas igualmente às razões de decidir." (BARROSO, Luís Roberto. O Controle de Constitucionalidade no Direito Brasileiro... p. 230).

57 "In a conversationalist theory of judicial review, for example, the role of courts is simply to deliberate, not to decide, so that weak remedies, because they entail less sacrifice of judicial efficacy, will almost always be preferred over weak rights. On the other hand, in a democratic minimalist understanding, a key part of the court's role is to resolve concrete controversies without resort to the kind of broad or deep judicial reasoning that can destabilize constitutional order, so that weak rights will almost always be preferred to weak remedies. Similarly, in a departmentalism understanding, the courts' role is simply to decide the particular concrete controversy; judicial opinions are not afforded any presumptive respect in the broader political process and, thus, nothing is lost when courts adopt a weak rights, as opposed to weak remedies, approach." (DIXON, Rosalind. Creating Dialogue about Socioecnomic Rights: Strong-form versus weak-form judicial review revisited. International Journal of Constitucional Law, v. 5, 2007. p. 411). 
Diante da dificuldade contramajoritária ${ }^{58}$ é mais produtivo defender apenas uma das várias formas de democracia e abandonar o constitucionalismo ou, alternativamente, enfrentar a tensão entre ambos e a necessidade de um compromisso?

Uma versão sofisticada do argumento em defesa do controle de constitucionalidade deve assinalar que os pré-requisitos ideais do processo democrático possuem valor epistêmico. ${ }^{59}$ A teoria epistêmica da democracia defendida por Carlos Santiago Nino, ao mesmo tempo em que questiona o uso do controle de constitucionalidade, apresenta três exceções. Nesse sentido, em determinados momentos, a fiscalização da constitucionalidade das decisões do parlamento se justificaria para garantir que elas sejam confiáveis ou eficazes.

A primeira exceção trata do controle do procedimento democrático. O procedimento democrático é o resultado de um conjunto (anterior) de regras e estas devem estar norteadas para a maximização epistêmica do processo político.$^{60} \mathrm{O}$ problema de fundo está na questão de entregar para a democracia a responsabilidade pela determinação da própria democracia. Por isso, a proposta de democracia procedimental é relevante, por levar em consideração a importância das condições das discussões e das decisões democráticas.

A segunda exceção trata da proteção da autonomia pessoal. O controle de constitucionalidade faz sentido contra políticas que procurem impor ideais perfeccionistas aos indivíduos ou ideais pessoais sobre toda a comunidade política. Para Nino, a razão para não seguir os mandamentos de uma legislação perfeccionista é que seu fundamento real se pauta em um ideal de excelência humana. ${ }^{61}$ Por isso, em tais situações, entende-se que os juízes podem interferir na legislação e afastar normas que visem impor um comportamento de excelência a todos os indivíduos e, como consequência, restringir seu campo de escolhas éticas.

Porém, as normas podem ser submetidas a um teste, se elas buscam um ideal de excelência humana elas podem ser objeto de fiscalização constitucional, se elas refletem a adoção de um standard moral intersubjetivo, elas são compatíveis com os processos políticos regulares e devem, em princípio, ser adotadas e corrigidas na arena política.

A terceira exceção sugerida por Nino se volta para a questão da eficácia e da preservação das práticas sociais fundadas na Constituição. O exercício

\footnotetext{
${ }^{58}$ BICKEL, Alexander. The Least Dangerous Branch: The Supreme Court at the Bar of Politics. New Haven: Yale University Press, 1986. p. 16.

59 "Una teoría alternativa para establecer una conexión apropiada entre el valor de la democracia y el control judicial de constitucionalidad sería argumentar que el primero requiere de ciertas precondiciones. Cuando los jueces interpretan la constitución y ésta prevalece por sobre la legislación ordinaria, están en realidad protegiendo esas precondiciones." (NINO, Carlos Santiago. La Constitución de la Democracia Deliberativa. Barcelona: Gedisa, 1997. p. 272).

${ }^{60}$ NINO, Carlos Santiago. La Constitución de la Democracia Deliberativa... p. 273.

${ }^{61}$ NINO, Carlos Santiago. La Constitución de la Democracia Deliberativa... p. 279.
} 
da fiscalização da constitucionalidade é justificado nos casos em que se têm como objetivo a proteção da convenção constitucional que garante a eficácia das próprias decisões democráticas. ${ }^{62}$ Busca-se preservar a possibilidade real de efetivação de dimensões ideais de uma determinada Constituição. Mesmo no caso de uma lei que cumpre os requisitos necessários da deliberação parlamentar, tal dispositivo pode se irradiar para obstar outras práticas democráticas. Em tais situações o controle de constitucionalidade poderia ser justificado, ainda que não exista uma "fórmula" que consiga estabelecer com precisão a ocorrência de tais casos. ${ }^{63}$

Em nossa realidade, não é possível - diante do papel atribuído para o STF pela Constituição -, e nem seria desejável, uma pura deferência do Judiciário diante dos outros Poderes. Tal disposição reduziria o Judiciário a um papel formal e simbólico no design institucional do Brasil.

\section{CONTROLE DE CONSTITUCIONALIDADE E NÍVEIS DE INTENSIDADE}

Em certas situações, a funcionalidade do controle de constitucionalidade identifica-se com a garantia da regularidade dos processos democráticos, substanciando, inclusive, um turno deliberativo adicional sobre eventual matéria em questionamento, o que implica qualificação do debate majoritário. Contudo, mesmo entre nós, ele não seria compatível com um modelo de justificação ativista que acreditasse que, em todos os casos, um grupo de juízes não eleitos possa decidir, de modo solipsista, a vida de toda a população.

O princípio da presunção da constitucionalidade se torna, por conseguinte, um guia fundamental para a atuação das Cortes. Derivado da separação dos poderes opera como limitador dos arroubos ativistas, como explica Barroso: "(...) não devem juízes e tribunais, como regra, declarar a inconstitucionalidade de lei ou ato normativo quando: a) a inconstitucionalidade não for patente e inequívoca, existindo tese jurídica razoável para preservação da norma; b) seja possível decidir a questão por outro fundamento, evitando-se a invalidação de ato de outro Poder; c) existir interpretação alternativa possível, que permita afirmar a compatibilidade da norma com a Constituição". ${ }^{44}$

Nos Estados Unidos, adota-se, no exercício da jurisdição constitucional, o "teste de três níveis" (three tier test) para a aferição do grau de legitimidade do texto legislativo impugnado. A decisão a respeito de qual tipo de escrutínio será submetida a legislação costuma ser respaldada nos precedentes da Corte. Na circunstância, envolvendo o caso violação a um direito fundamental,

\footnotetext{
${ }^{62}$ NINO, Carlos Santiago. La Constitución de la Democracia Deliberativa... p. 281.

63 "Es, en última instancia, una cuestión de juicio si está justificado limitar el funcionamiento de la democracia, no para promover directamente la democracia como en el primer caso de control judicial de constitucionalidad, sino para preservar una práctica que le otorga eficacia a las decisiones democráticas." (NINO, Carlos Santiago. La Constitución de la Democracia Deliberativa... p. 282).

${ }^{64}$ BARROSO, Luís Roberto. Curso de Direito Constitucional Contemporâneo... p. 300. No mesmo sentido ver: SOUZA NETO, Cláudio Pereira de; SARMENTO, Daniel. Direito Constitucional: teoria, história e métodos de trabalho. Belo Horizonte: Fórum, 2012. p. 458.
} 
mais rigoroso será o controle, ou seja, quanto mais importante o direito, mais ativa será a atuação por parte da Corte em sua tutela.

O mais básico dos testes é o da racionalidade (rational basis review) ou escrutínio mínimo (minimum scrutiny). Qualquer lei submetida ao controle de constitucionalidade passa por esse teste, independentemente de qual conteúdo ela verse. Trata-se de um juízo bastante elementar, no qual a demanda argumentativa no sentido da justificação da constitucionalidade da lei é baixa. O teste é superado com a simples demonstração de que a lei constitui um meio racional e razoável para a persecução de um determinado fim legítimo. Caracteriza-se, portanto, como um escrutínio que privilegia a deferência por parte da Corte em relação à legislação produzida pelo Congresso. Os exemplos mais recorrentes envolvem casos cuidando de matéria econômica. ${ }^{65}$

O segundo nível de escrutínio é o intermediário (intermediate scrutiny). Caracteriza-se por demandar que o governo prove que a lei questionada trata de um interesse importante e, mais, que existe uma relação substantiva entre tal interesse e a prescrição legal. ${ }^{66}$ Com fulcro na cláusula da "igual proteção" (14 Emenda da Constituição dos Estados Unidos), verifica-se, por meio de tal teste, de maneira mais rigorosa, a constitucionalidade de leis envolvendo discriminação de gênero e casos de restrição à liberdade de expressão. ${ }^{67}$ Realiza-se, com este tipo de escrutínio, o teste das classificações "quasesuspeitas".

Em seu último nível, o controle de constitucionalidade supõe escrutínio estrito (strict scrutiny), a gradação mais elevada sendo manejada pela Corte em casos bastante precisos, em especial quando o legislador adota

\footnotetext{
${ }^{65}$ Atribui-se a James Thayer uma das defesas mais radicais no sentido da deferência do Judiciário: THAYER, James Bradley. The Origin and Scope of the American Doctrine of Constitutional Law. Boston: Little, Brown and Company, 1893. Sobre a relação entre Tahyer e o escrutínio mínimo, ver: FALLON JR., Richard H. Strict Judicial Scrutiny. University of California Law Review, v. 54, 2007. Outro exemplo histórico relevante está na dissidência de Holmes em Lochner v. New York (1905): "[A] Constitution is not intended to embody a particular economic theory, whether of paternalism and the organic relation of the citizen to the state or of laissez faire. It is made for people of fundamentally differing views (...) I think that the word 'liberty', in the $14^{\text {th }}$ Amendment, is perverted when it is held to prevent the natural outcome of a dominant opinion, unless it can be said that a rational and fair man necessarily would admit that the statute proposed would infringe fundamental principles (...)". Sobre a relação entre Holmes e Thayer ver: POSNER, Richard. The Rise and Fall of Judicial Self-Restraint. California Law Review, v. 100, 2012. p. 526.

${ }^{66} \mathrm{Em}$ Craig v. Boren (1976) o Justice Brennnan afirmou que: "To withstand constitutional challenge, previous cases establish that classifications by gender must serve important governmental objectives and must be substantially related to achievement of those objectives". Deriva-se desse caso a criação do segundo nível de escrutínio.

${ }^{67}$ No caso Clark v. Jeter (1988), a Justice O'Connor estabeleceu que: "Between [the] extremes of rational basis review and strict scrutiny lies a level of intermediate scrutiny, which generally has been applied to discriminatory classifications based on sex or illegitimacy. To withstand intermediate scrutiny, a statutory classification must be substantially related to an important governmental objective". A lei da Pensilvânia que determinava que a uma "criança ilegítima" deveria provar a paternidade antes de buscar ajuda de seu pai e que o prazo para tanto era até os seis anos foi declarada inconstitucional pela Suprema Corte.
} 
classificações suspeitas - tais como restrições no direto ao voto e nos direitos de não discriminação ${ }^{68}$-, mas também quando adota classificações que onerem direitos fundamentais, como nas garantias previstas na $4^{\mathrm{a}}$ Emenda da Constituição dos Estados Unidos, ${ }^{69}$ ou no acesso aos tribunais. ${ }^{70}$

O escrutínio estrito exige a demonstração, pela autoridade, de que a classificação adotada pelo ato impugnado satisfaça três requisitos para ter sua legitimidade reconhecida pela Corte: ${ }^{71}$ i) ela deve refletir um interesse imperioso (compelling); ii) deve ser estabelecida sob medida (narrowly tailored) para atingir o interesse; iii) e deve ser o meio menos restritivo (least restictive means) necessário para atingir tal finalidade. ${ }^{72}$

Ainda que a Corte não tenha definido de maneira mais precisa qual o conceito de um interesse governamental imperioso, entende-se que diz respeito a algo necessário, crucial, em sentido inverso de algo que pode ser escolhido com maior discricionariedade por seus agentes políticos.

Se a política desenvolvida pelo governo não for produzida sob medida para atingir seu objetivo, transbordando os limites do interesse público, a norma não pode ser considerada adequada. ${ }^{73}$

\footnotetext{
${ }^{68}$ No caso Grutter $v$. Bollinger a Justice O'Connor observou que: "We have held that all racial classifications imposed by government 'must be analyzed by a reviewing court under strict scrutiny.' (...) We have never held that the only governmental use of race that can survive strict scrutiny is remedying past discrimination. Nor, since Bakke, have we directly addressed the use of race in the context of public higher education. Today, we hold that the Law School hás a compelling interest in attaining a diverse student body. (...) We [also] find that the Law School's admissions program bears the hallmarks of a narrowly tailored plan." Grutter v. Bollinger (2003).

${ }^{69}$ Que protege os indivíduos de buscas, sem fundamentação, em sua propriedade e seus documentos e demanda a necessidade de uma causa provável (probable cause) para a realização de buscas e apreensões.

${ }^{70}$ MORO, Sergio Fernando. Legislação Suspeita? Afastamento da Presunção de Constitucionalidade da Lei. 2. ed., Curitiba: Juruá Editora, 2003.

71 "(...) extremamente rigoroso, em que ocorre praticamente uma inversão na presunção de constitucionalidade do ato normativo." (SOUZA NETO, Cláudio Pereira de; SARMENTO, Daniel. Direito Constitucional... p. 459).

${ }^{7}$ Uma comparação entre os níveis de escrutínio e a proporcionalidade foi feita da seguinte maneira: "The first stage of PA mandates inquiry into the 'suitability' of the measure under review. The government must demonstrate that the relationship between the means chosen and the ends pursued is rational and appropriate, given a stated policy purpose. This mode of scrutiny is broadly akin to what Americans call 'rational basis' review, although under PA, the appraisal of government motives and choice of means is more searching. In most systems, few laws are struck down at this stage. The second step - 'necessity'- embodies what Americans know as a 'narrow tailoring' requirement. At the core of necessity analysis is a least restrictive-means (LRM) test, through which the judge ensures that the measure at issue does not curtail the right more than is necessary for the government to achieve its goals. (...) The third step - balancing stricto sensu is also known as 'proportionality in the narrow sense'. In the balancing phase, the judge weighs, in light of the facts, the benefits of the act (already found to have been narrowly tailored) against the costs incurred by infringement of the right, in order to decide which side shall prevail." (MATHEWS, Jud; SWEET, Alec Stone. All Things in Proportion? American Rights Doctrine and the Problem of Balancing. Emory Law Journal, v. 60, 2011. p. 106-107).

${ }^{73}$ Ver Adarand Constructors, Inc. v. Peña (1995): "The decision here makes explicit that federal racial classifications, like those of a State, must serve a compelling governmental interest, and
} 
Além disso, a lei ou a política deve adotar os meios menos restritivos na persecução do interesse. Ainda que tal avaliação possa ser realizada em conjunto com a anterior, a Suprema Corte acaba por efetivar uma análise separada de cada um dos aspectos relacionados à constitucionalidade da lei.

A demanda por um escrutínio mais exigente (more exacting judicial scrutiny), foi derivada da Nota de Rodapé $\mathrm{n}^{\circ} 4$ de Carolene Products, e de seu projeto de justificação do controle de constitucionalidade no sentido do desenvolvimento de um standard elevado para a fiscalização, o qual complementaria o controle baseado na racionalidade (rational basis), nos casos de direitos que demandassem atenção especial.

Compreende-se que o escrutínio estrito foi criado não como um mecanismo para afastar a constitucionalidade de qualquer lei, mas como instrumento que procurou combinar elementos doutrinários de diferentes tempos para controlar leis em defesa de direitos. ${ }^{74} \mathrm{O}$ uso expresso do termo aconteceu em um caso posterior, em Skinner v. Oklahoma (1942). ${ }^{75}$

A Suprema Corte americana, porém, nem sempre soube manejar de maneira adequada esse conjunto de instrumentais. O caso Korematsu $v$. United States (1944) é um exemplo de que mesmo diante de um escrutínio rígido, ${ }^{76}$ a Corte pode falhar, adotando uma postura deferente equivocada ao confirmar a

must be narrowly tailored to further that interest. Thus, to the extent that Fullilove held federal racial classifications to be subject to a less rigorous standard, it is no longer controlling. Requiring strict scrutiny is the best way to ensure that courts will consistently give racial classifications a detailed examination, as to both ends and means. It is not true that strict scrutiny is strict in theory, but fatal in fact".

${ }^{74}$ MATHEWS, Jud; SWEET, Alec Stone. All Things in Proportion? p. 130-131. Deve-se lembrar que o caso Carolene Products foi menos uma introdução de um nível de escrutínio mais rigoroso e mais uma mudança do foco - no sentido da deferência - do controle de constitucionalidade. (WINKLER, Adam. Fatal in Theory and Strict in Fact: An Empirical Analysis of Strict Scrutiny in the Federal Courts. Vanderbilt Law Review, v. 59, 2006. p. 799). Para Tribe, em Carolene Products a Suprema Corte declarou que manteria regulações na esfera socioeconômica se qualquer conjunto de fatos conhecidos, ou que pudessem ser inferidos, suportassem a decisão política. Tal controle limitado acabou por se tornar quase que em uma abdicação judicial completa. A Corte passou a usar fatos e razões hipotéticas para manter leis sobre economia e saúde ou mesmo, em certos casos, sem qualquer razão substantiva. TRIBE, Laurence. American Constitutional Law. 3. ed., New York: Foundation Press, 2000. p. 1362.

${ }^{75}$ A Suprema Corte decidiu que a lei de Oklahoma que previa a possibilidade da esterilização de criminosos após a terceira condenação configurava uma ofensa a um importante direito fundamental, o direito à reprodução. Além disso, a não previsão da esterilização para crimes de colarinho branco violava a Cláusula de Igual Proteção da $14^{\mathrm{a}}$ Emenda Constitucional: "He is forever deprived of a basic liberty. We mention these matters not to reexamine the scope of the police power of the States. We advert to them merely in emphasis of our view that strict scrutiny of the classification which a State makes in a sterilization law is essential, lest unwillingly or otherwise invidious discriminations are made against groups or types of individuals in violation of the constitutional guaranty of just and equal laws".

76 "It should be noted, to begin with, that all legal restrictions which curtail the civil rights of a single racial group are immediately suspect. That is not to say that all such restrictions are unconstitutional. It is to say that courts must subject them to the most rigid scrutiny. Pressing public necessity may sometimes justify the existence of such restrictions; racial antagonism never can". 
constitucionalidade de uma Ordem Executiva que determinou a prisão de nipo-americanos em campos de internamento durante a Segunda Guerra Mundial, independentemente de possuírem ou não cidadania americana. ${ }^{77}$

Não obstante, mesmo com o risco de emergência de juízo falho, defende-se o manejo de standards que possam orientar o exercício da fiscalização da constitucionalidade, o que não exclui, ao contrário exige, a apreciação simultânea de outros dados decorrentes da conjuntura política, do diagnóstico do momento histórico, da densidade deliberativa à qual a matéria foi exposta, considerados também os precedentes e a coerência do romance em cadeia. ${ }^{78}$

Os standards, aproveitada a ideia dos níveis distintos de escrutínio, são úteis para a discussão sobre os parâmetros para o controle de constitucionalidade no Brasil. Não visam, por isso, afastar outras formulações análogas que possam refinar as considerações apresentadas. Por outro lado, poderiam pensar alguns que uma dogmática constitucional emancipatória implica prática em descompasso com as exigências democráticas porque instrumentalizadora de um suposto ativismo judicial. Nada mais falso. É verdade que esta dogmática preocupa-se com a realização dos comandos constitucionais, em particular aqueles tratando dos direitos fundamentais. E nesse passo, acredita no importante papel a ser desenvolvido pelo Judiciário brasileiro, sobretudo no exercício da jurisdição constitucional. Nem por isso propõe um papel para o juiz que esteja além daquele desenhado pela arquitetônica da organização dos poderes da Constituição ou que implique indevida compressão do campo de escolhas legítimas do legislador a partir de um processo aberto de deliberação com repercussão na arena pública. ${ }^{79}$

O Judiciário ocupado com as promessas constitucionais não será nem ativista, nem deferente, com as escolhas do legislador. Operará, conforme o caso, mas sempre a partir de bases racionais com sustentação na Lei Fundamental, ora um controle mais forte, ora um controle mais débil do ato (omissivo ou comissivo) impugnado. Transitará entre a auto-contenção,

\footnotetext{
77 "The story of Japanese Americans and strict scrutiny begins with Hirabayashi v. United States and Korematsu v. United States. In these cases, the Court justified its upholding of race-based restrictions on American citizens of Japanese ancestry on the grounds of the exceptional demands of wartime military necessity." (ROBINSON, Greg; ROBINSON, Toni. Korematsu and Beyond: Japanese Americans and the origins of strict scrutiny. Law and Contemporary Problems, v. 68, 2005. p. 30).

${ }^{78}$ DWORKIN, Ronald. O Império do Direito. Também podem ser utilizados os seguintes critérios: "(1) O primeiro aspecto a ser considerado é o grau de legitimidade democrática do ato normativo. (...) (2) A democracia também deve calibrar a autocontenção judicial num sentido inverso. (...) (3) Critério igualmente importante se relaciona à proteção de minorias estigmatizadas. (...) (4) Outro critério diz respeito à relevância material do direito fundamental em jogo. (...) (5) Outro importante elemento a ser considerado é a comparação entre as capacidades institucionais do Poder Judiciário e do órgão que editou o ato normativo discutido. (...) (6) Finalmente, outro elemento a ser considerado é a época de edição do ato normativo." (SOUZA NETO, Cláudio Pereira de; SARMENTO, Daniel. Direito Constitucional... p. 460-463).

${ }^{79}$ CLÈVE, Clèmerson Merlin. Para uma Dogmática Constitucional Emancipatória. Belo Horizonte: Fórum, 2012.
} 
prestando deferência à escolha do legislador, e o controle mais forte (ativismo) para a proteção desta ou daquela situação. ${ }^{80}$

Em qualquer caso, porém, deverá adotar postura vigilante a respeito dos postulados da democracia (que implicam autogoverno e definição de escolhas prioritariamente através do processo público de deliberação). Há momentos, como aqueles que envolvem a defesa de minorias contra a discriminação, a proteção da liberdade de manifestação e de opinião, a proteção do mínimo existencial, verdadeiras condições para o exercício da democracia, exigentes de um controle forte do Judiciário.

Há outros, ao contrário, desafiantes, prima facie, de uma postura de auto-contenção, de deferência para com a decisão do legislador. São necessários argumentos muito robustos para justificar, em casos assim, uma ação distinta do órgão judicial. Cite-se, por exemplo, as questões difíceis que supõem interpretação de cláusulas constitucionais (abertas) autorizadoras de concepções distintas e razoáveis num ambiente de pluralismo moral.

Nesses casos, em princípio, a escolha do legislador, tomada a partir de um processo público de deliberação, não deve ser substituída pela do juiz. Aqui, sim, ocorrente a substituição, manifestar-se-ia hipótese eventualmente contrastante com a experiência democrática.

Não se trata, para o juiz, portanto, de agir contra a democracia, mas, antes, para a democracia. Quer-se uma sociedade de livres e iguais, não uma sociedade inadequadamente paternalista, onde o juiz possa agir como uma espécie de pai caridoso. Dito isso, é necessário reiterar que, diante de uma Constituição analítica, ampla, como a nossa, muitas questões que antes remanesciam no exclusivo campo da política, são, agora, levadas ao Judiciário em função de escolha operada pelo Constituinte. Mas aqui, mais uma vez, cumpre lembrar que judicialização não implica necessariamente ativismo.

Em síntese, entre nós é defensável a tese no sentido de que o manejo de um controle de constitucionalidade forte, ou de um escrutínio mais estrito, faz sentido nas seguintes circunstâncias:

A) para a defesa das condições para o exercício da democracia em matérias que envolvam i) liberdade de opinião (direito ao protesto ${ }^{81}$ e censura ao discurso silenciador) ${ }^{82}$; ii) proteção do processo democrático (regularidade

\footnotetext{
${ }^{80}$ CLÈVE, Clèmerson Merlin. Jurisdição Constitucional, Ativismo e Democracia. Conferência de Abertura na IX Convenção Latino-americana de Direito (Colad), Curitiba, Paraná, em 27 de outubro de 2011.

${ }^{81}$ Ver: GARGARELLA, Roberto. El Derecho a la Protesta: el primer derecho. Buenos Aires: Ad-Hoc, 2005. Para quem o direito ao protesto é o "primeiro direito", permite demandar a recuperação dos outros direitos.

${ }^{82}$ Fiss procura redefinir o papel do Estado no que tange à liberdade de expressão. Ao invés de apenas pensar em tal direito em termos antagônicos com o Estado, seria possível ver a liberdade de expressão como um direito público, instrumento da autodeterminação coletiva, e o Estado como um "amigo da liberdade" de expressão. FISS, Owen. Libertad de Expresión y Estructura Social. México, D.F.: Fontamara, 1997. p. 13-14.
} 
do processo legislativo e controle do poder político ou econômico no processo eleitoral) ${ }^{83}$; iii) proteção de minorias (legislação suspeita ou com presunção de inconstitucionalidade) ${ }^{84}$; iv) outros direitos básicos naquilo que é condição necessária (embora não suficiente) para a proteção da dignidade humana ${ }^{85} \mathrm{e}$ v) direitos sociais, ${ }^{86}$ em particular os prestacionais, nos casos de eficácia originária ou diante da defesa do mínimo existencial ${ }^{87}$ (que não se confunde com o mínimo vital), verdadeiras condições materiais para a democracia.

83 "(...) refletindo assim um compromisso constitucional cada vez mais forte com a ideia de que
todos os cidadãos qualificados para tal devem participar da tomada de decisões públicas." (ELY,
John Hart. Democracia e Desconfiança: uma teoria do controle judicial de constitucionalidade. São Paulo: Martins Fontes, 2010. p. 165).

${ }^{84}$ De acordo com o tipo de discriminação e como ela incide sobre uma minoria. Em casos de "classificações suspeitas" o nível de escrutínio por parte da Corte precisa ser elevado para proteger as minorias. Algumas leis podem "passar no teste", mas a maioria deve acabar por ser declarada inconstitucional diante da dificuldade por parte do governo em justificar a medida discriminatória. Além disso, no caso de classificações "quase suspeitas", o nível intermediário de escrutínio é recomendado. Contudo, nem a própria definição de "classificações suspeitas" é pacífica. Alguns Tribunais podem enfatizar a questão da minoria ser "discreta e insular", outros podem se concentrar na imutabilidade de características do grupo e ainda também podem enfatizar com o histórico de discriminação relacionado ao grupo minoritário. Para Marcy Strauss: "Thus, although described in different ways, the basic factors for determining suspect class status were in place by the early 1980s: (1) prejudice against a discrete and insular minority; (2) history of discrimination against the group; (3) the ability of the group to seek political redress (i.e., political powerlessness); (4) the immutability of the group's defining trait; and (5) the relevancy of that trait. Using some combination of these factors, the Court has deemed various groups suspect, others quasi-suspect, and still others nonsuspect since the 1970s. Facial classifications based on race, national origin, and religion are considered suspect and receive strict scrutiny. Gender and illegitimacy are considered quasi-suspect and receive intermediate scrutiny. Age, socioeconomic status, and mental disability are subject to rational basis review. All other classifications (such as sexual orientation) either have not been decided or are reviewed under the default rational basis standard." (STRAUSS, Marcy. Reevaluating Suspect Classifications. Seattle University Law Review, v. 35, 2011. p. 146).

${ }^{85}$ De acordo com Barroso: “(...) deve-se aceitar uma noção de dignidade humana aberta, plástica e plural. Grosso modo, esta é a minha concepção minimalista: a dignidade humana identifica 1. O valor intrínseco de todos os seres humanos; assim como 2. A autonomia de cada indivíduo; e 3. Limitada por algumas restrições legítimas impostas a ela em nome de valores sociais ou interesses estatais (valor comunitário)." (BARROSO, Luís Roberto. A Dignidade da Pessoa Humana no Direito Constitucional Contemporâneo: a construção de um conceito jurídico à luz da jurisprudência mundial. Belo Horizonte: Fórum, 2012. p. 72).

86 “(...) eles são, em sentido material, direitos a ações positivas fáticas, que, se o indivíduo tivesse condições financeiras e encontrasse no mercado oferta suficiente, poderia obtê-las de particulares, porém, na ausências destas condições e, considerando a importância destas prestações, cuja outorga ou não-outorga não pode permanecer nas mãos da simples maioria parlamentar, podem ser dirigidas contra o Estado por força de disposição constitucional." (LEIVAS, Paulo Gilberto Cogo. Teoria dos direitos fundamentais sociais. Porto Alegre: Livraria do Advogado, 2006. p. 89).

87 "O mínimo existencial, na qualidade de direito fundamental, exibe, como este, as suas facetas de direito subjetivo e de norma objetiva. Como direito subjetivo investe o cidadão na faculdade de acionar as garantias processuais e institucionais na defesa dos seus direitos mínimos. Do ponto de vista objetivo o mínimo existencial aparece como norma de declaração de direitos fundamentais, que deve cobrir o campo mais amplo das pretensões da cidadania. Mas, sendo pré-constitucional, não lhe prejudica a eficácia a circunstância de se encontrar implícito no discurso constitucional." (TORRES, Ricardo Lobo. O Direito ao Mínimo Existencial. Rio de Janeiro: Renovar, 2009. p. 38-39). 
B) contra leis perfeccionistas, de esquerda (todos devem ser solidários, generosos, bons e virtuosos) ou de direita (criminalização indevida de condutas - adultério, relações homoafetivas, etc.). ${ }^{88}$

A jurisdição constitucional guarda os valores substantivos necessários para a legítima deliberação pública. Porém, isso não é suficiente, tais valores substantivos devem ser interpretados por todos aqueles que venham a ser afetados pela decisão, por isso a importância da preservação de espaços deliberativos e instituições que transformem as manifestações plurais advindas da sociedade em direitos.

Os espaços em que tais manifestações ocorrem podem ser tanto no âmbito representativo clássico, mas também, através de outras formas menos tradicionais. Precisa-se reconhecer, por exemplo, a importância que as audiências públicas e o amicus curiae possuem para qualificar as razões do exercício da jurisdição constitucional. Um eventual protagonismo judicial pode se justificar diante da necessidade republicana de protagonismo popular.

Além dos casos que reclamam uma postura ativa por parte da Corte, entende-se que outras ocasiões demandam um controle débil (soft), a autocontenção ou deferência para com as decisões do legislador:

A) no caso de políticas públicas instrumentalizadoras de direitos sociais naquilo que se reporta à eficácia derivada ou que exceda as fronteiras do mínimo existencial.

B) nas questões eminentemente políticas, considerando, sempre, porém, que tais questões não constituem cláusula imunizadora. Há necessidade de respeito à dimensão política da vida e da discricionariedade legislativa em relação àquilo que não é obrigatório constitucionalmente. Seria forçoso justificar a interferência do Judiciário em decisões típicas dos outros Poderes, como na escolha de Ministros, ou no veto presidencial, por exemplo.

C) nos resultados plebiscitários, referendários, leis de iniciativa popular, momentos constituintes ${ }^{89}$ e, mesmo, leis novas que resultam de um processo regular e aberto de deliberação, deve-se, como regra, prestar deferência diante dos resultados e das razões do legislador.

Não se trata aqui de admitir uma postura procedimentalista. Trata-se de, no processo argumentativo e deliberativo levado a termo pelo Judiciário, considerar, com peso adequado, as razões do legislador. Nesses casos há uma presunção forte de constitucionalidade das leis, a qual pode, não obstante, ser

\footnotetext{
${ }^{88}$ A legislação perfeccionista pode se apresentar de diferentes maneiras, por isso, envolve discussões sobre o controle sobre o consumo de drogas, de bebida no trânsito, de cigarros em ambientes públicos e o direito à saúde. O perfeccionismo se caracteriza por entender que aquilo que é bom para um indivíduo ou satisfaz seus interesses é independente de seus próprios desejos ou da escolha de sua forma de vida, logo, cabe ao Estado escolher quais valores e planos de vida são objetivamente melhores para os indivíduos. NINO, Carlos Santiago. Ética y Derechos Humanos: un ensayo de fundamentación. Buenos Aires: Astrea, 1989.

${ }^{89}$ ACKERMAN, Bruce. We The People: Foundations. Cambridge: Harvard University Press, 1993.
} 
afastada por outras razões, mesmo não populares, mas determinantes. É bom lembrar que o juiz constitucional figura como um guardião dos princípios permanentes da comunidade política constitucionalizada.

Por fim, deve-se reconhecer a existência de um conjunto de questões difíceis que, quando judicializadas, em poucas ocasiões serão resolvidas de modo tranquilo. Temas que envolvem o direito à vida, eutanásia, aborto, por exemplo, colocam à prova, como questões limites, os fundamentos de quaisquer teorias que procurem oferecer solução ao problema da tensão entre o controle de constitucionalidade e o governo da maioria. Cuida-se, aqui, de problemas que indicam a impossibilidade da formulação de consensos, já que supõem apresentação de razões que podem ser utilizadas na defesa de distintos pontos de vista com idêntico suporte constitucional.

Tais casos, embora causem consternação, nem sempre podem "aguardar" deliberações densas por parte do Legislativo ou mesmo do Judiciário. Em tais circunstâncias, decide-se, porque não há outro caminho, devendo-se, via de regra, preferir as soluções razoáveis e atuais oferecidas pelo Legislador.

\section{CONCLUSÃO}

Em um limitado diagnóstico de época, percebe-se que o papel do Supremo Tribunal Federal tem mudado. Essa nova feição, entretanto, ainda está em construção e nem todas as roldanas e parafusos foram ajustados. Ora, esse novo papel precisa ser discutido, com humildade, abertura e raciocínio crítico. Impõe-se, no caso, advertir que o Supremo Tribunal Federal não está fora do jogo político. Como em qualquer ambiente democrático, ${ }^{90}$ as decisões judiciais, sendo corretas ou não, precisam ser cumpridas. Isso não quer dizer que não possam ser, na arena pública, com o devido respeito e com bons argumentos, questionadas. Afinal, em uma sociedade aberta, o voto vencido de ontem pode ser o voto condutor de amanhã.

\section{BIBLIOGRAFIA}

ACKERMAN, Bruce. We The People: Foundations. Cambridge: Harvard University Press, 1993.

ARISTOTLE. Politics. London: William Heinemann, 1932.

BARROSO, Luís Roberto. A Dignidade da Pessoa Humana no Direito Constitucional Contemporâneo: a construção de um conceito jurídico à luz da jurisprudência mundial. Belo Horizonte: Fórum, 2012.

BARROSO, Luís Roberto. Curso de Direito Constitucional Contemporâneo: os conceitos fundamentais e a construção do novo modelo. São Paulo: Saraiva, 2009.

\footnotetext{
90 "I maintain that democracy should not be understood as simple majoritarianism - let the political branches have their say - but rather as a deep and broad-based deliberative process in which we - all of us - give content to the values that define us as a nation. Constitutional pronouncements do not prevent or even stifle such deliberations, but rather, by fully revealing the threat that is posed to our basic commitments, give such deliberations a certain vitality." (FISS, Owen. The Perils of Minimalism. Theoretical Inquires in Law, v. 9, 2008. p. 647-648).
} 
BARROSO, Luís Roberto. Judicialização, Ativismo Judicial e Legitimidade Democrática. Revista de Direito do Estado, n 13, jan./mar. 2009.

BARROSO, Luís Roberto. O Controle de Constitucionalidade no Direito Brasileiro: exposição sistemática da doutrina e análise crítica da jurisprudência. São Paulo: Saraiva, 2011.

BARROSO, Luís Roberto. O Novo Direito Constitucional Brasileiro: contribuições para a construção teórica e prática da jurisdição constitucional no Brasil. Belo Horizonte: Fórum, 2012.

BICKEL, Alexander. The Least Dangerous Branch: The Supreme Court at the Bar of Politics. New Haven: Yale University Press, 1986.

BINENBOJM, Gustavo. A Nova Jurisdição Constitucional. 2. ed., Rio de Janeiro: Renovar, 2004.

CAMPOS, Carlos Alexandre de Azevedo. Dimensões do Ativismo Judicial do Supremo Tribunal Federal. Rio de Janeiro: Forense, 2014.

CANOTILHO, J. J. Gomes. Direito Constitucional e Teoria da Constituição. 7. ed., Coimbra: Almedina, 2003.

CLĖVE, Clèmerson Merlin. A Fiscalização Abstrata de Constitucionalidade no Direito Brasileiro. 2. ed., São Paulo: RT, 2000.

CLÉVE, Clèmerson Merlin. Atividade Legislativa do Poder Executivo. São Paulo: Revista dos Tribunais, 2011.

CLÈVE, Clèmerson Merlin. Jurisdição Constitucional, Ativismo e Democracia. Conferência de Abertura na IX Convenção Latino-americana de Direito (Colad), Curitiba, Paraná, em 27 de outubro de 2011.

CLÈVE, Clèmerson Merlin. Medidas Provisórias. 3. ed., São Paulo: RT, 2010.

CLÈVE, Clèmerson Merlin. Para uma Dogmática Constitucional Emancipatória. Belo Horizonte: Fórum, 2012.

CLÉVE, Clèmerson Merlin. Temas de Direito Constitucional. 2. ed., Belo Horizonte: Fórum, 2014.

CLÈVE, Clèmerson Merlin; FREIRE, Alexandre. Direitos Fundamentais e Jurisdição Constitucional. São Paulo: Editora RT, 2014.

DIXON, Rosalind. Creating Dialogue about Socioecnomic Rights: Strong-form versus weak-form judicial review revisited. International Journal of Constitucional Law, v. 5, 2007.

DWORKIN, Ronald. Levando os Direitos a Sério. São Paulo: Martins Fontes, 2010.

DWORKIN, Ronald. O Império do Direito. São Paulo: Martins Fontes, 2003.

DWORKIN, Ronald. Uma Questão de Princípio. São Paulo: Martins Fontes, 2005.

ELY, John Hart. Democracia e Desconfiança: uma teoria do controle judicial de constitucionalidade. São Paulo: Martins Fontes, 2010.

FALLON JR., Richard H. Strict Judicial Scrutiny. University of California Law Review, V. 54, 2007.

FEREJOHN, John. Judicializing Politics, Politicizing Law. Law and Contemporary Problems, v. 65, n 3, 2002.

FISS, Owen. Libertad de Expresión y Estructura Social. México, D.F.: Fontamara, 1997.

FISS, Owen. The Perils of Minimalism. Theoretical Inquires in Law, v. 9, 2008. 
GARGARELLA, Roberto. El Derecho a la Protesta: el primer derecho. Buenos Aires: Ad-Hoc, 2005.

HABERMAS, Jürgen. Between Facts and Norms. Cambridge: The MIT Press, 1998.

HABERMAS, Jürgen. Theory and Practice. Boston: Beacon Press, 1973.

HIRST, Paul. Representative Democracy and its Limits. Cambridge: Polity Press, 1990. HOBBES, Thomas. Leviatã. São Paulo: Ícone, 2000.

KELSEN, H. Jurisdição Constitucional. São Paulo: Martins Fontes, 2007.

LEIVAS, Paulo Gilberto Cogo. Teoria dos Direitos Fundamentais Sociais. Porto Alegre: Livraria do Advogado, 2006.

MATHEWS, Jud; SWEET, Alec Stone. All Things in Proportion? American Rights Doctrine and the Problem of Balancing. Emory Law Journal, v. 60, 2011.

MENDES, Conrado Hübner. Controle de Constitucionalidade e Democracia. Rio de Janeiro: Elsevier, 2008.

MENDES, Conrado Hübner. Direitos Fundamentais, Separação de Poderes e Deliberação. São Paulo: Saraiva, 2011.

MENDES, Gilmar Ferreira; BRANCO, Paulo Gustavo Gonet. Curso de Direito Constitucional. 7. ed., São Paulo: Saraiva, 2012.

MORO, Sergio Fernando. Legislação Suspeita? Afastamento da Presunção de Constitucionalidade da Lei. 2. ed., Curitiba: Juruá Editora, 2003.

MOUFFE, Chantal. El Retorno de lo Político. Barcelona: Paidós, 1999.

NETTO, Menelick de Carvalho; SCOTTI, Guilherme. Os Direitos Fundamentais e a (In)certeza do Direito: a produtividade das tensões principiológicas e a superação do sistema de regras. Belo Horizonte: Fórum, 2011.

NINO, Carlos Santiago. Ética y Derechos Humanos: un ensayo de fundamentación. Buenos Aires: Astrea, 1989.

NINO, Carlos Santiago. La Constitución de la Democracia Deliberativa. Barcelona: Gedisa, 1997.

POSNER, Richard. The Rise and Fall of Judicial Self-Restraint. California Law Review, v. 100, 2012.

ROBINSON, Greg; ROBINSON, Toni. Korematsu and Beyond: Japanese Americans and the origins of strict scrutiny. Law and Contemporary Problems, v. 68, 2005.

SARMENTO, Daniel. Direitos Fundamentais e Relações Privadas. Rio de Janeiro: Lumen Juris, 2003.

SILVA, Virgílio Afonso da. Direitos Fundamentais: conteúdo essencial, restrições e eficácia. 2. ed., São Paulo: Malheiros, 2010.

SOUZA NETO, Cláudio Pereira de; SARMENTO, Daniel. Direito Constitucional: teoria, história e métodos de trabalho. Belo Horizonte: Fórum, 2012.

STRAUSS, David A. The Living Constitution. Oxford: Oxford University Press, 2010.

STRAUSS, Marcy. Reevaluating Suspect Classifications. Seattle University Law Review, v. 35, 2011.

SUNSTEIN, Cass. If People Would be Outraged by Their Rulings, Should Judges Care? Stanford Law Review, v. 60, 2007. 
THAYER, James Bradley. The Origin and Scope of the American Doctrine of Constitutional Law. Boston: Little, Brown and Company, 1893.

TORRES, Ricardo Lobo. O Direito ao Mínimo Existencial. Rio de Janeiro: Renovar, 2009.

TRIBE, Laurence. American Constitutional Law. 3. ed., New York: Foundation Press, 2000.

TRIBE, Laurence. The Invisible Constitution. New York: Oxford University Press, 2008. VELASCO, Marina. O que é Justiça: o justo e o injusto na pesquisa filosófica. Rio de Janeiro: Vieira \& Lent, 2009.

VIEIRA, Oscar Vilhena. A Constituição como Reserva de Justiça. Lua Nova, n 42, 1997.

WINKLER, Adam. Fatal in Theory and Strict in Fact: An Empirical Analysis of Strict Scrutiny in the Federal Courts. Vanderbilt Law Review, v. 59, 2006. 